\title{
Perbedaan Tingkat Pengetahuan Dan Sikap Ibu Terhadap Kelengkapan Imunisasi Dasar Wajib Di Wilayah Kerja Puskesmas Hutarakyat Kecamatan Sidikalang Kabupaten Dairi Tahun 2019
}

\author{
Regina Saely Sitanggang ${ }^{1}$, Ade Pryta R. Simaremare ${ }^{2}$, Saharnauli J Verawaty Simorangkir ${ }^{3}$ \\ ${ }_{1}^{1}$ Mahasiswa Fakultas Kedokteran Universitas HKBP Nommensen \\ ${ }^{2}$ Departeman Mikrobiologi Fakultas Kedokteran Universitas HKBP Nommensen \\ ${ }^{3}$ Departemen Anatomi Fakultas Kedokteran Universitas HKBP Nommensen \\ Korespondensi: Regina Saely Sitanggang, Email: reginaasaely@gmail.com
}

\begin{abstract}
Background: Immunization is an effort to raise/enhance immunity against a disease actively, if one day body is exposed to the disease, it will not get sick or it will get mild illness. According to the 2013 and 2018 Riskesdas data on complete obligatory basic immunization coverage in Indonesia it was found decrease from $59.2 \%$ to $57.9 \%$. Obligatory basic immunization coverage in Dairi Regency in 2016 - 2017 has decreased, in 2016 (83.7\%) and 2017 $(81.3 \%)$.

Objective: To determine the differences in the level of knowledge and attitudes of mothers with the completeness of obligatory basic immunizations in the working area of the Hutarakyat Health Center in 2019.

Methods: This was an analytical study with a case control design. The study sample was 76 respondents taken by consecutive sampling. Data collected is using questionnaire.

Results: The results of this study showed that of 76 respondents, mothers who brought their babies for immunization in 2019 had the most adulthood (77.6\%), had higher education (69.7\%), had a non-working status $(60.5 \%)$, had good knowledge $(65.9 \%)$, and had a positive attitude $(62.5 \%)$. Toward immunization there were significant differences in the level of knowledge and attitudes of mothers towards the completeness of obligatoty basic immunization.
\end{abstract}

Conclusions: There were differences in the level of knowledge and attitudes of mothers with the completeness of obligatory basic immunizations.

Keywords: Obligatory basic immunization, knowledge, attitude.

\begin{abstract}
Abstrak
Latar Belakang: Imunisasi adalah suatu upaya untuk menimbulkan/meningkatkan kekebalan seseorang secara aktif terhadap suatu penyakit, sehingga apabila suatu saat terpajan dengan penyakit tersebut tidak akan sakit atau hanya mengalami sakit ringan. Menurut data Riskesdas tahun 2013 dan 2018 data cakupan imunisasi dasar wajib lengkap di Indonesia didapati menurun dari 59,2\% menjadi 57,9\%. Cakupan imunisasi dasar wajib lengkap di Kabupaten Dairi tahun 2016 - 2017 telah terjadi penurunan yaitu 87,7\% (tahun 2016) menjadi 81,3\% (tahun 2017)
\end{abstract}

Tujuan: Untuk mengetahui perbedaan tingkat pengetahuan dan sikap ibu terhadap kelengkapan imunisasi dasar wajib di wilayah kerja Puskesmas Hutarakyat tahun 2019.

Metode: Penelitian ini merupakan penelitian analitik dengan desain case control. Sampel penelitian sebanyak 76 orang diambil secara consecutive sampling. Pengumpulan data dilakukan dengan menggunakan kuesioner. 
Hasil: Hasil penelitian ini menunjukkan dari 76 responden, ibu yang membawa bayinya untuk imunisasi tahun 2019 paling banyak usia dewasa awal $(77,6 \%)$, memiliki pendidikan tinggi $(69,7 \%)$, memiliki status tidak bekerja $(60,5 \%)$, memiliki pengetahuan baik $(65,9 \%)$, dan memiliki sikap positif $(62,5 \%)$. Pada analisis bivariat terdapat perbedaan yang signifikan pada tingkat pengetahuan dan sikap ibu terhadap kelengkapan imunisasi dasar wajib.

Kesimpulan: Terdapat perbedaan tingkat pengetahuan dan sikap ibu terhadap kelengkapan imunisasi dasar wajib.

Kata kunci: Imunisasi dasar wajib, pengetahuan, sikap

\section{Pendahuluan}

Imunisasi sangat diperlukan demi memberikan perlindungan, pencegahan, sekaligus membangun kekebalan tubuh anak terhadap berbagai penyakit menular maupun penyakit berbahaya yang dapat menimbulkan kecacatan tubuh, bahkan kematian. ${ }^{1,2}$ World Health Organization (WHO) mengatakan imunisasi sebagai alat yang terbukti untuk mengendalikan penyakit menular yang mengancam jiwa dan dapat mencegah antara dua hingga tiga juta kematian setiap tahun. ${ }^{3}$ Anak-anak yang menerima vaksin terbukti terlindungi dari penyakit menular yang dapat menyebabkan penyakit serius atau kecacatan dan berakibat fatal. 4,5 Namun saat ini di Indonesia masih ada anak-anak yang belum mendapatkan imunisasi secara lengkap bahkan tidak pernah mendapatkan imunisasi sedari lahir. Hal itu menyebabkan mereka mudah tertular penyakit berbahaya karena tidak adanya kekebalan terhadap penyakit tersebut. ${ }^{6}$

Dalam program imunisasi di Indonesia, pemberian Imunisasi Dasar Lengkap (IDL) pada bayi, merupakan suatu keharusan. ${ }^{1}$ Imunisasi dasar merupakan salah satu upaya untuk menurunkan angka kesakitan dan kematian pada bayi. ${ }^{7}$ Imunisasi Dasar Lengkap tercapai jika bayi telah mendapat imunisasi Hepatitis B, BCG, DTP, Polio, dan campak sebelum berusia satu tahun. Imunisasi BCG hanya dianjurkan bagi negara endemis. Indonesia saat ini merupakan negara ke-3 tertinggi di dunia untuk penyakit TBC, setelah India dan Tiongkok $1,8,9$

Indikator yang diukur untuk menilai keberhasilan pelaksanaan imunisasi yaitu Universal Child Immunization (UCI) desa/kelurahan. Cakupan UCI desa/kelurahan menurut Provinsi pada tahun 2016 di Sumatera Utara adalah $(73,44 \%) .{ }^{10}$ Untuk cakupan imunisasi dasar lengkap di Kabupaten Dairi tahun 2016 - 2017 telah terjadi penurunan diantaranya tahun $2016(83,7 \%)$ dan tahun $2017(81,3 \%)^{11}$. Dari data tersebut dapat dikatakan bahwa masih ada bayi yang imunisasinya tidak lengkap serta bayi yang belum pernah di imunisasi.

Ada beberapa hal yang mempengaruhi belum tercapainya target cakupan imunisasi antara lain rumor yang salah tentang imunisasi, masyarakat berpendapat imunisasi menyebabkan anaknya menjadi sakit, cacat atau bahkan meninggal dunia, pemahaman masyarakat terutama orang tua yang masih kurang tentang imunisasi,serta usia dan pekerjaan ibu. ${ }^{8}$ Berdasarkan hasil penelitian tersebut maka peneliti tertarik untuk mengetahui perbedaan tingkat pengetahuan, dan sikap ibu dengan kelengkapan imunisasi dasar wajib.

\section{Metode}

Penelitian ini merupakan penelitian analitik dengan pendekatan case control, yaitu membedakan antara tingkat pengetahuan dan sikap kelompok ibu yang anaknya mendapatkan imunisasi dasar wajib lengkap (kasus) dengan kelompok ibu yang anaknya mendapatkan imunisasi dasar wajib tidak lengkap (kontrol). Penelitian ini dilaksanakan di wilayah kerja puskesmas Hutarakyat Kecamatan Sidikalang Kab. Dairi. Luas wilayah kerja puskesmas Hutarakyat adalah $35,69 \mathrm{~km}^{2}$.

Sampel dalam penelitian ini adalah seluruh ibu yang membawa bayinya yang berusia 9-12 bulan untuk dilakukan imunisasi di wilayah kerja Puskesmas Hutarakyat Kecamatan Sidikalang Kab.Dairi pada bulan Januari 2019. Pemilihan sampel pada penelitan ini dilakukan dengan menggunakan teknik consecutive sampling dan diperoleh 76 orang responden.

Instrumen penelitian yang digunakan dalam penelitian ini dibuat dalam bentuk kuesioner yaitu tingkat pengetahuan dan sikap tentang imunisasi dasar dan kelengkapan imunisasi dasar di wilayah kerja Puskesmas Hutarakyat Kecamatan Sidikalang. Pernyataan pada tingkat pengetahuan berbentuk skala gutman yang terdiri dari 20 soal dengan pilihan jawaban menggunakan benar dan salah. Untuk sikap berbentuk skala likert yang terdiri dari 10 soal dengan pilihan jawaban sangat setuju, setuju, kurang setuju, dan tidak setuju. Pada pernyataan kelengkapan imunisasi dasar yang akan dinilai dengan melihat pencatatan KMS maupun register imunisasi sesuai dengan umurnya didasarkan pada standar jadwal pemberian imunisasi. ${ }^{7}$

\section{Hasil}

Tabel 1 menunjukkan bahwa berdasarkan karakteristik menurut usia paling banyak berusia 20-35 tahun sebanyak 59 orang $(77,6 \%)$, kemudian usia $36-45$ sebanyak 17 orang $(22,4 \%)$. Berdasarkan karakteristik menurut tingkat pendidikan yakni, $\leq \mathrm{SMP}$ sebanyak 10 orang $(13,2 \%)$, $\geq$ SMA sebanyak 66 orang $(86,8 \%)$. Berdasarkan karakteristik menurut pekerjaan yakni, bekerja sebanyak 30 orang $(39,5 \%)$, dan tidak bekerja sebanyak 46 orang $(60,5 \%)$. Tabel 2 menunjukkan bahwa dari 41 orang yang memiliki pengetahuan baik, terdapat 27 orang $(65,9 \%)$ anaknya mendapat imunisasi dasar lengkap, dan dari 40 orang yang memiliki sikap positif, terdapat 25 orang $(62,5 \%)$ anaknya mendapat imunisasi lengkap.

Tabel 3 menunjukkan bahwa dari 59 orang yang berusia dewasa awal, terdapat 31 orang $(29,5 \%)$ anaknya mendapat imunisasi 
Tabel 1 Karakteristik Responden

\begin{tabular}{|c|c|c|c|}
\hline Karakteristik Responden & Kategori & Jumlah & $\%$ \\
\hline \multirow{2}{*}{ Usia } & Dewasa awal (20-35 tahun) & 59 & $77,6 \%$ \\
\hline & Dewasa akhir (36-45 tahun) & 17 & $22,4 \%$ \\
\hline \multirow{2}{*}{ Pendidikan } & Rendah (SSMP) & 10 & $13,2 \%$ \\
\hline & Tinggi ( $\geq$ SMA) & 53 & $69,7 \%$ \\
\hline \multirow{2}{*}{ Pekerjaan } & Bekerja & 30 & $39,5 \%$ \\
\hline & Tidak bekerja & 46 & $60,5 \%$ \\
\hline Total & & 76 & $100 \%$ \\
\hline
\end{tabular}

Tabel 2 Distribusi Frekuensi Pengetahuan dan Sikap Responden dengan Kelengkapan

\begin{tabular}{lllll}
\hline \multirow{2}{*}{ Variabel } & \multicolumn{2}{c}{ Imunisasi lengkap } & \multicolumn{2}{c}{ Imunisasi tidak lengkap } \\
\cline { 2 - 5 } & $\mathbf{n}$ & $\%$ & $\mathbf{n}$ & $\%$ \\
\hline Pengetahuan & & & & \\
$\quad$ Baik & 27 & $65,9 \%$ & 14 & $34,1 \%$ \\
$\quad$ Kurang & 11 & $31,4 \%$ & 24 & $68,6 \%$ \\
Sikap & & & & \\
Positif & 25 & $62,5 \%$ & 15 & $37,5 \%$ \\
Negatif & 13 & $36,1 \%$ & 23 & $63,9 \%$ \\
\hline Total & $\mathbf{3 8}$ & $\mathbf{1 0 0 \%}$ & $\mathbf{3 8}$ & $\mathbf{1 0 0 \%}$ \\
\hline
\end{tabular}

Tabel 3 Hubungan Usia, Tingkat Pendidikan, dan Pekerjaan Ibu dengan Kelengkapan

\begin{tabular}{|c|c|c|c|c|c|c|c|}
\hline \multirow{2}{*}{\multicolumn{2}{|c|}{ Karakteristik Responden }} & \multirow{2}{*}{\multicolumn{2}{|c|}{ Imunisasi Lengkap }} & \multicolumn{2}{|c|}{$\begin{array}{c}\text { Imunisasi Tidak } \\
\text { Lengkap }\end{array}$} & $p$ & \multirow[t]{2}{*}{ OR } \\
\hline & & & & & & & \\
\hline & & $\mathrm{n}$ & \multirow{3}{*}{$\begin{array}{c}\% \\
52,5 \% \\
41,2 \%\end{array}$} & \multirow{3}{*}{$\begin{array}{c}\mathrm{n} \\
28 \\
10\end{array}$} & \multirow{3}{*}{$\begin{array}{c}\% \\
47,5 \% \\
58,8 \%\end{array}$} & & \\
\hline Usia lbu & Dewasa awal & 31 & & & & 0,682 & 1,582 \\
\hline & Dewasa akhir & 7 & & & & $0,08<$ & $1,08<$ \\
\hline \multirow[t]{2}{*}{ Tingkat Pendidikan Ibu } & Rendah & 2 & $20,0 \%$ & 8 & $80,0 \%$ & \multirow{2}{*}{0,042} & \multirow{2}{*}{0,208} \\
\hline & Tinggi & 36 & $54,5 \%$ & 30 & $45,5 \%$ & & \\
\hline \multirow[t]{2}{*}{ Pekerjaan lbu } & Bekerja & 13 & $43,3 \%$ & 17 & $56,7 \%$ & \multirow{2}{*}{0,348} & \multirow{2}{*}{0,881} \\
\hline & Tidak bekerja & 25 & $54,3 \%$ & 21 & $45,7 \%$ & & \\
\hline
\end{tabular}

dasar lengkap, dan dari 17 orang yang berusia dewasa akhir, terdapat 7 orang $(52,5 \%)$ anaknya mendapat imunisasi lengkap. Hasil uji chi-square pada tabel 3 untuk umur menunjukkan nilai $p$ $>0,05$, artinya tidak terdapat hubungan usia ibu terhadap kelengkapan imunisasi dasar wajib, selanjutnya didapati nilai $\mathrm{OR}=$ 1,58 artinya ibu yang memiliki usia dewasa awal 1,58 kali lebih berpeluang anaknya mendapat imunisasi dasar lengkap dibanding dengan ibu yang memiliki usia dewasa akhir. Berdasarkan pendidikan ibu, dari 10 orang yang berpendidikan rendah, terdapat 2 orang (20,0\%) anaknya mendapat imunisasi dasar lengkap, dan dari 66 orang yang berpendidikan tinggi, terdapat 36 orang $(45,5 \%)$ anaknya mendapat imunisasi lengkap.

Hasil uji chi-square pada tabel 4 untuk pendidikan menunjukkan nilai $p<0,05$, artinya terdapat hubungan pendidikan ibu terhadap kelengkapan imunisasi dasar wajib, namun didapati nilai OR= 0,208 artinya tidak ada perbedaan bermakna antara pendidikan ibu yang rendah dan tinggi dalam mengimunisasikan bayinya. Berdasarkan pekerjaan ibu, dari 27 orang yang bekerja, terdapat 13 orang $(43,3 \%)$ anaknya mendapat imunisasi dasar lengkap, dan dari 46 orang yang tidak bekerja, terdapat 25 orang $(54,3 \%)$ anaknya mendapat imunisasi lengkap. Hasil uji chi-square untuk pekerjaan menunjukkan nilai $p>0,05$, artinya tidak terdapat hubungan pekerjaan ibu terhadap kelengkapan imunisasi dasar wajib. Selanjutnya didapati nilai $\mathrm{OR}=0,881$ artinya tidak ada perbedaan bermakna antara ibu yang bekerja dan tidak bekerja dalam mengimunisasikan bayinya.

Hasil uji chi-square pada tabel 4 untuk pengetahuan me-nunjukkan nilai $p<0,05$, artinya terdapat hubungan pengetahuan ibu terhadap kelengkapan imunisasi dasar wajib bayi, selanjutnya didapat nilai $O R=4,20$ artinya ibu yang memiliki pengetahuan baik 4,20 kali lebih berpeluang anaknya mendapat imunisasi dasar lengkap dibanding dengan ibu yang memiliki pengetahuan kurang. Hasil uji chi-square untuk sikap menunjukkan nilai $p<0,05$, artinya terdapat hubungan sikap ibu terhadap kelengkapan imunisasi dasar wajib bayi, selanjutnya didapat nilai $\mathrm{OR}=2,94$ artinya ibu yang memiliki sikap positif 2,94 kali lebih berpeluang anaknya mendapat imunisasi dasar lengkap dibanding dengan ibu yang memiliki sikap negatif.

\section{Pembahasan}

Karakteristik responden berdasarkan usia, tingkat pendidikan, dan pekerjaan ditunjukkan oleh tabel 1. Dari tabel didapati berdasarkan usia, ibu yang membawa bayinya untuk imunisasi paling banyak usia dewasa awal (20-35 tahun), yaitu sebanyak 45 orang $(59,2 \%)$. Usia dewasa awal (20-35 tahun) merupakan usia paling produktif dan umur paling ideal dalam pembentukan kegiatan kesehatan. Hasil uji chi-square pada tabel 3 untuk usia menunjukkan nilai $p=$ 0,409 ( $p>0,05$ ), artinya tidak terdapat hubungan usia ibu terhadap kelengkapan imunisasi dasar wajib. Selanjutnya didapati nilai OR= 
1,58 artinya ibu yang memiliki usia dewasa awal 1,58 kali lebih berpeluang anaknya mendapat imunisasi dasar lengkap dibanding dengan ibu yang memiliki usia dewasa akhir. Tidak adanya hubungan karena usia ibu yang memiliki bayi dengan status imunisasi tidak lengkap dan ibu yang memiliki bayi dengan status imunisasi lengkap sebagian besar berusia dewasa awal, sehingga tidak terdapat sebaran usia lainnya pada responden. Hasil penelitian ini sesuai dengan penelitian Adzaniyah dan Chatarina yang menyatakan tidak ada hubungan antara usia responden atau usia ibu dengan status kelengkapan imunisasi bayi karena ibu lebih banyak pada usia $<25$ tahun. ${ }^{12}$ Hasil penelitian ini tidak sesuai dengan penelitian yang dilakukan oleh Githa Sekar Prihanti,dkk yang menyatakan terdapat hubungan yang signifikan antara usia ibu dengan kelengkapan imunisasi dasar, karena usia merupakan salah satu sifat karakteristik orang yang sangat utama, sehingga mempunyai hubungan yang sangat erat dengan berbagai sifat seseorang. ${ }^{12}$ Namun usia ibu bukanlah satu satunya faktor yang mempengaruhi kelengkapan imunisasi, banyak faktor lain yang mempengaruhi kelengkapan imunisasi, salah satunya adalah tingkat pendidikan. ${ }^{13}$

Berdasarkan tingkat pendidikan ibu, paling banyak adalah tamatan SMA, yaitu sebanyak 53 orang $(69,7 \%)$. Hasil uji chi-square pada tabel 3 untuk pendidikan menunjukkan nilai $p=0,042(<0,05)$, artinya terdapat hubungan pendidikan ibu terhadap kelengkapan imunisasi dasar wajib. Selanjutnya didapati nilai $O R=0,208$ artinya tidak ada perbedaan bermakna antara pendidikan ibu yang rendah dan tinggi dalam mengimunisasikan bayinya. Ibu yang memilik pendidikan, lebih baik dalam pencegahan penyakit dan kesadaran terhadap masalah-masalah kesehatan. ${ }^{14}$ Semakin tinggi tingkat pendidikan seseorang maka semakin baik pula pengetahuannya. ${ }^{15,16}$. Penelitian ini sejalan dengan penelitian yang dilakukan oleh Riska Harmasdiyani yang menyatakan bahwa pendidikan ibu mempengaruhi cara berfikir dalam menentukan kepatuhan melaksanakan imunisasi dasar lengkap. Semakin tinggi pendidikan ibu diharapkan dapat berfikir lebih baik berkaitan dengan kesehatan anaknya sehingga patuh memberikan imunisasi dasar lengkap. ${ }^{17}$

Berdasarkan pekerjaan, ibu paling banyak membawa anaknya untuk diimunisasi adalah ibu rumah tangga sebanyak 46 orang $(60,5 \%)$. Hasil uji chi-square pada tabel 3 untuk pekerjaan menunjukkan nilai $p=0,348 \quad(>0,05)$, artinya tidak terdapat hubungan pekerjaan ibu terhadap kelengkapan imunisasi dasar wajib. Selanjutnya didapati nilai $\mathrm{OR}=0,881$ artinya tidak ada perbedaan bermakna antara ibu yang bekerja dan tidak bekerja dalam mengimunisasikan bayinya. Ibu yang bekerja maupun tidak bekerja mempunyai kesempatan yang sama untuk memperoleh informasi tentang imunisasi dasar baik dari petugas kesehatan maupun berbagai media seperti TV, radio, dan surat kabar. ${ }^{17}$ Namun menurut penelitian yang dilakukan Rice dkk, menyebutkan bahwa terdapat hubungan antara pekerjaan dengan kepatuhan ibu dalam pemberian imunisasi di wilayah kerja puskesmas Tamalanrea. Ibu yang bekerja dapat bertukar informasi dengan teman sekerja yang lebih terpapar dengan program-program kesehatan, khususnya imunisasi. Sehingga pekerjaan mempengaruhi kepatuhan ibu dalam pemberian imunisasi. ${ }^{16}$
Hasil penelitian ini menunjukkan bahwa pada kelompok imunisasi dasar lengkap proporsi ibu yang memiliki pengetahuan baik terhadap kelengkapan imunisasi dasar wajib yaitu 27 orang $(65,9 \%)$, sedangkan pada kelompok imunisasi dasar tidak lengkap proporsi ibu yang memiliki pengetahuan baik terhadap kelengkapan imunisasi dasar wajib yaitu 14 orang $(34,1 \%)$. Selanjutnya dari hasil analisis bivariat dengan menggunakan uji chi-square yang didapati adalah nilai $p=0,003(p<0,05)$, sehingga dari hasil analisis di atas ditemukan bahwa terdapat hubungan yang signifikan antara pengetahuan ibu terhadap kelengkapan imunisasi dasar wajib bayi. Selanjutnya didapat nilai $O R=4,20$ artinya ibu yang memiliki pengetahuan baik 4,20 kali lebih berpeluang anaknya mendapat imunisasi dasar lengkap. Berdasarkan wawancara dengan responden, ibu yang memiliki pengetahuan baik lebih sering mengikuti penyuluhan yang diadakan pada berbagai kegiatan posyandu di wilayah kerja Puskesmas Hutarakyat, sedangkan ibu yang memiliki pengetahuan kurang jarang mengikuti penyuluhan tersebut. Hal ini dikarenakan oleh beberapa faktor, yaitu ibu tidak memiliki waktu untuk hadir pada penyuluhan tersebut, beberapa ibu mengatakan bahwa kadang-kadang lupa jadwal imunisasi karena sibuk dengan pekerjaan hingga malam, dan ibu tidak mengetahui frekuensi pemberian imunisasi pada bayi.

Pengetahuan merupakan hasil tahu dan terjadi setelah seseorang melakukan penginderaan terhadap suatu objek tertentu. Menurut Notoatmodjo pengetahuan merupakan faktor penting yang mendasari seseorang untuk membentuk suatu perilaku, didapati bahwa perilaku yang didasari oleh pengetahuan akan lebih bertahan lama dibanding dengan perilaku yang tidak didasari dengan pengetahuan. ${ }^{18}$ Faktor lain yang mempengaruhi pengetahuan ibu yaitu pemberian informasi oleh petugas kesehatan, paparan media massa seperti televisi, dan surat kabar. Semakin banyak ibu memperoleh informasi tentang imunisasi dasar lengkap maka semakin baik pula pengetahuannya, sebaliknya semakin sedikit informasi tentang imuniasi dasar lengkap yang diperoleh maka semakin kurang pengetahuannya. ${ }^{29}$ Peran Puskesmas Hutarakyat melalui kader kesehatan dan pemegang program imunisasi melalui penyuluhan merupakan faktor utama dalam penambahan informasi terhadap ibu sehingga ibu memiliki pengetahuan mengenai imunisasi. Hasil penelitian ini sesuai dengan penelitian yang dilakukan Dewi Nur Intan Sari, menyatakan bahwa bayi dari ibu yang berpengetahuan baik mempunyai peluang untuk memperoleh imunisasi dasar lengkap 2,652 kali lebih besar dibandingkan dengan bayi dari ibu yang berpengetahuan kurang baik. ${ }^{20}$

Hasil penelitian ini menunjukkan bahwa pada kelompok imunisasi dasar lengkap proporsi ibu yang memiliki sikap positif terhadap kelengkapan imunisasi dasar wajib yaitu 25 orang $(62,5 \%)$, sedangkan pada kelompok imunisasi dasar tidak lengkap proporsi ibu yang memiliki sikap positif terhadap kelengkapan imunisasi dasar wajib yaitu 15 orang (37,5\%). Selanjutnya dari hasil analisis bivariat pada tabel 6 dengan menggunakan uji chi-square yang didapati adalah nilai $p=0,022(p<0,05)$ sehingga dari hasil analisis diatas ditemukan bahwa terdapat hubungan yang signifikan antara sikap ibu terhadap kelengkapan imunisasi dasar wajib bayi. Selanjutnya didapat nilai OR $=2,94$ artinya ibu yang memiliki sikap positif 2,94 kali lebih berpeluang anaknya mendapat imunisasi 
dasar lengkap. Berdasarkan wawancara dengan responden, ibu dengan sikap positif lebih aktif dalam mengikuti kegiatan imunisas yang diadakan oleh posyandu di wilayah kerja Puskesmas Hutarakyat. Sedangkan ibu dengan sikap negatif lebih pasif dalam mengikuti kegiatan imunisasi tersebut. Hal ini dikarenakan oleh beberapa faktor, yaitu ketakutan ibu terhadap kejadian ikutan pasca imunisasi yang dapat menyebabkan anak menjadi sakit, dan keyakinan ibu yang menganggap bahwa imunisasi haram/ tidak boleh diberikan pada bayi. ${ }^{12}$

Sikap merupakan respon tertutup seseorang terhadap objek tertentu yang melibatkan faktor pendapat dan emosi yang bersangkutan. Faktor yang berperan penting dalam menentukan sikap seseorang adalah pengetahuan. Oleh karena itu, pengetahuan yang baik akan memberikan pengaruh pada sikap yang baik. ${ }^{18}$ Hasil penelitian ini sejalan dengan penelitian yang dilakukan oleh Miftahol Hudha dan Atik Choirul Hidajah tahun 2017 menyatakan bahwa sikap ibu yang baik lebih lengkap status imunisasi bayinya. Selain itu sikap dapat dipengaruhi oleh faktor pengalaman pribadi, pengaruh orang lain yang dianggap penting, pengaruh kebudayaan, media massa, lembaga pendidikan dan lembaga agama. 21,22

\section{Kesimpulan}

Ibu yang membawa bayinya untuk imunisasi pada pada penelitian ini paling banyak berusia 20-35 tahun, memiliki pendidikan terakhir tingkat SMA, dan memiliki status tidak bekerja, memiliki tingkat pengetahuan baik dan sikap positif. Terdapat hubungan pendidikan, tingkat pengetahuan dan sikap ibu terhadap kelengkapan imunisasi dasar wajib.

\section{Ucapan Terima Kasih}

Penulis menyampaikan terima kasih bagi pihak Dinas Kesehatan Kecamatan Sidikalang Kabupaten Dairi terkhusus Puskesmas Hutarakyat atas kerjasama yang baik selama pengumpulan data dari responden pada kegiatan Posyandu yang dilaksanakan selama bulan Februari 2019.

\section{Daftar Pustaka}

1. Kementrian Kesehatan Republik Indonesia. Buku Ajar Imunisasi. (Mulati E, Isfan R, Fatimah O, Widyaningsih Y, eds.). Jakarta: Kementrian Kesehatan Rl; 2015. doi:351.077 Ind r

2. Rezeki S. The Value of vaccination. In: Ranuh IGNG, Hariyanto Suyitno D, eds. Pedoman Imunisasi Di Indonesia. 4th ed. Jakarta: Badan Penerbit Ikatan Dokter Anak Indonesia; 2011:10.

3. WHO. Immunization [Internet]. World Health Organization. 2018. Tersedia pada: http://www.who.int/topics/immunization/en/.

4. Ikatan Dokter Anak Indonesia. Immunisasi : Seputar pekan imunisasi dunia 2018 [Internet]. Ikatan Dokter Anak Indonesia. 2018 [dikutip 10 Desember 2018]. Tersedia pada: http://www.idai.or.id/artikel/klinik/imunisasi/seputarpekan-imunisasi-dunia-2018.

5. WHO. Immunization coverage [Internet]. World Health Organization. 2017 [dikutip 13 Desember 2018]. Tersedia pada: https://www.who.int/newsroom/fact-sheets/detail/immunization-coverage.

6. Departemen Kesehatan Republik Indonesia. Berikan anak imunisasi rutin lengkap, ini rinciannya [Internet]. Departemen Kesehatan Republik Indonesia. 2018 [dikutip 3 Oktober 2018]. Tersedia pada: http://www.depkes.go.id/article/print/18043000011/berikan-anak-imunisasirutin-lengkap-ini-rinciannya.htm.
7. Selvia E. Hubungan pengetahuan dan sikap ibu balita terhadap tindakan imunisasi dasar lengkap di Kelurahan Lambung Bukit Kota Padang tahun 2014. J Kesehat Andalas. 2017;6(2):1.

8. Triana V. Faktor yang berhubungan dengan pemberian imunisasi dasar lengkap pada bayi Tahun 2015. JKMA (Jurnal Kesehat Masy Andalas) (Andalas J Public Heal. 2016;10(2):123-135. doi:10.24893/jkma.10.2.123135.2016

9. Rusmil K. Melengkapi/mengejar imunisasi (bagian II). Ikatan Dokter Anak Indonesia.

10. Kementrian Kesehatan Republik Indonesia. Laporan Kinerja Direktorat Jendral Pencegahan Dan Pengendalian Penyakit Tahun 2017; 2017.

11. Dinas Kesehatan Republik Indonesia. Profil Kesehatan Kabupaten Dairi. Sidikalang; 2017

12. Rahmawati Al, Umbul C. Faktor yang mempengaruhi kelengkapan imunisasi dasar di Kelurahan Krembangan Utara. J Berk Epidemiol. 2014;2(1):64.

13. Prihanti GS, Rahayu MP, Abdullah MN. Faktor-faktor yang mempengaruhi status kelengkapan imunisasi dasar di wilayah kerja Puskesmas $\mathrm{X}$ kota Kediri. J IImu Kesehat dan Kedokt Kel. 2016;12(2):125.

14. Wani RT, dkk. Knowledge, attitude and practices of mother with children under five years of age about vaccination. J Med Sci Clin Res. 2017;5(4):24452.

15. Murti A. Pengetahuan ibu menyusui tentang ASI eksklusif. Jurnal Kesehatan Samodra IImu. 2016;7(2); hal. 119

16. Mandowa R. Faktor-faktor yang berhubungan dengan kepatuhan ibu dalam pemberian imunisasi dasar di wilayah kerja puskesmas Tamalanrea. J IIm Kesehat Diagnosis. 2014;5(4):419.

17. Harmasdiyani R. Pengaruh karakteristik ibu terhadap ketidakpatuhan pemberian imunisasi dasar lengkap pada anak bawah dua tahun. J Berk Epidemiol. 2016;3(310)

18. Notoatmodjo S. IImu Perilaku Kesehatan. Jakarta: Rineka Cipta; 2014.

19. Ramad HA, Soliman SM, El-Kader RGA. Knowledge, attitude and practice of mothers toward children's obligatory vaccination. IOSR J Nurs Heal Sci. 2016;5(4):24-27.

20. Sari, D. Hubungan pengetahuan ibu tentang imunisasi dasar dengan kelengkapan imunisasi dasar bayi di wilayah kerja puskesmas Bendo Kabupaten Magetan. Biomedika. 2016;8(2):9.

21. Azwar S. Sikap Manusia. 2nd ed. Yogyakarta: Pustaka pelajar; 2017.

22. Hudhah M, Hidajah AC. Perilaku ibu dalam imunisasi dasar lengkap di puskesmas Gayam Kabupaten Sumenep. J Promkes. 2017;5(2):167-180. 